\title{
ADOLPH ZBOŘIL - AN AUSTRIAN OFFICER IN THE TRANSV AAL ARTILLERY
}

\section{Erwin A. SchmidI*}

Whereas the German Major Richard Albrecht, the Commander of the Orange Free State Artillery, is a well-known figure of South African military history, this is not the case with Captain Adolph Zbořil. Zbořil (a Czech name, pronounced 'Sbor-shil') from 1886 to 1893 held the second-highest rank in the Transvaal Artillery. Admittedly, his achievements were less spectacular - and convincing - than Albrecht's and he left the Transvaal Artillery six years before the outbreak of the Second Anglo-Boer War. Still, it seems worthwhile to trace Zbořil's career

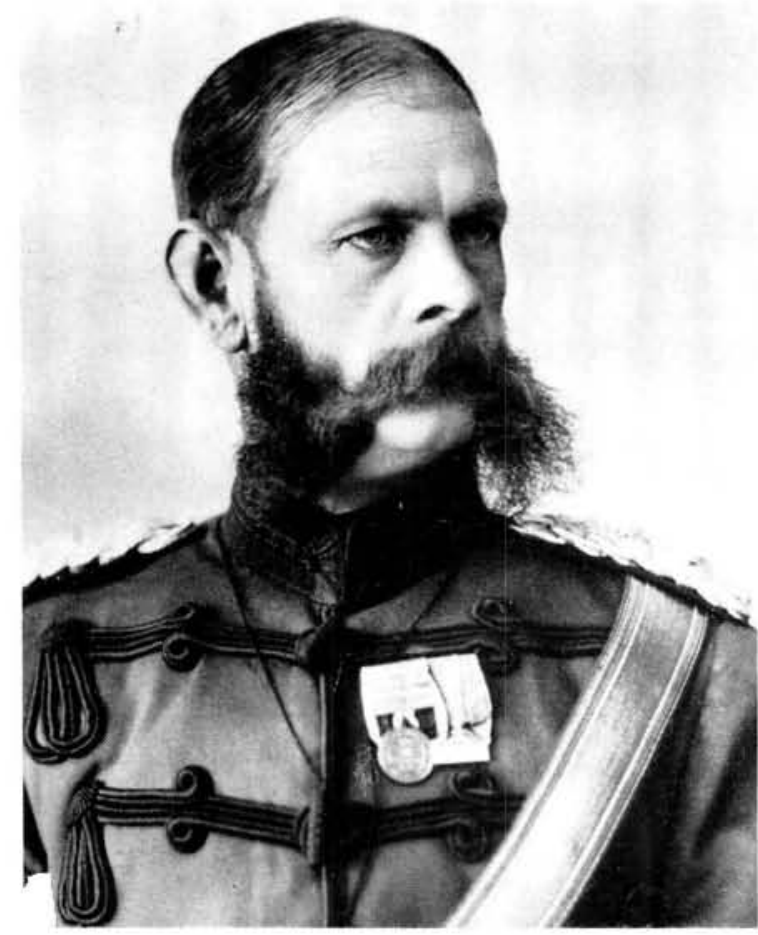

Captain R.F.N. Albrecht, commander of the Orange Free State Artillery. (Photo: Cultural History Museum)

\section{The happy fraternity days in Vienna}

Adolph was a son of Jakob Zbořil, a businessman from Zöptau in Moravia (then part of Austria-Hungary, now Sobotin in the People's Republic of Czechoslovakia). Adolph was born on 10 October 1853; there were at least two brothers. Jakob Zbořil owned a wood- and steel trading firm in Vienna and belonged to the well-todo upper middle-class. His firm was the Vienna representation of several important industries and Jakob Zboril was a member of the Vienna
Spar-und Credit-Casse's (Vienna savings and credit bank) council.

After high school, Adolph Zbořil studied engineering from 1869, first at the renowned Polytechnikum in Zurich (Switzerland) and then in Munich (Bavaria). In 1871, he returned to Vienna to continue his studies at what was then the Polytechnikum (now Technical University), starting with the winter semester $1871 / 72$. $^{1)}$

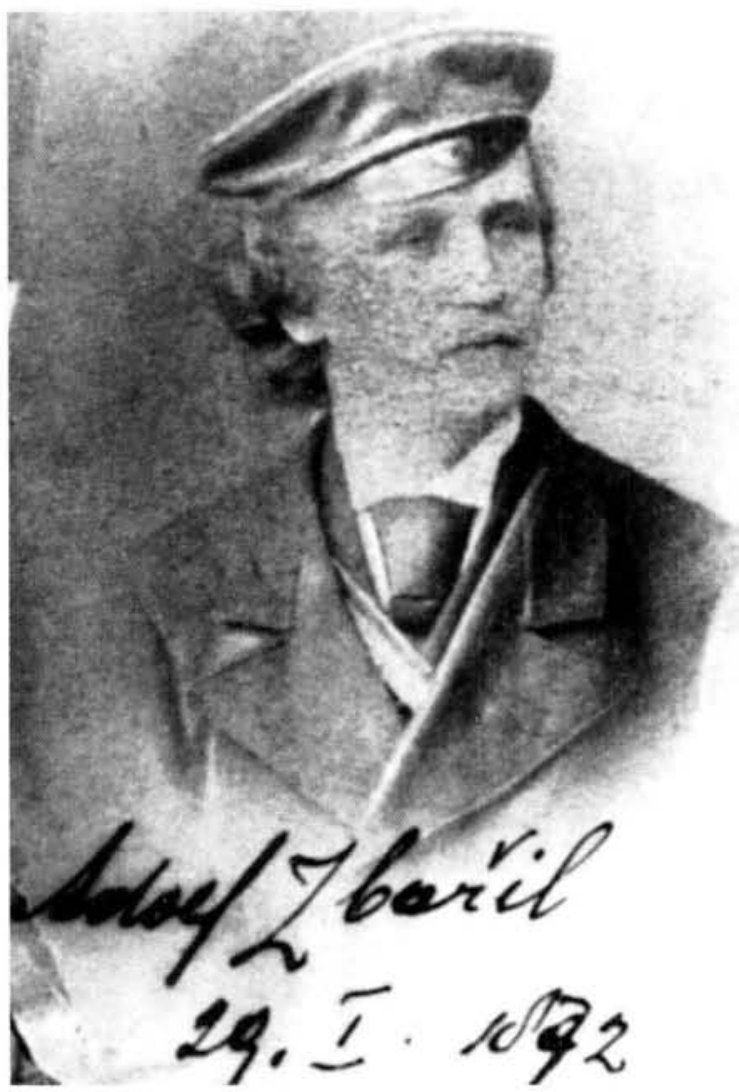

A. Zboril as a student in Vienna, wearing the cap and band of the "Alemannia" fraternity. (Photo: HR Dr. Rabe via Schmidl)

Besides his studies, Zbořil was active in fraternity life. In Zurich, he had belonged to a shortlived fraternity called "Silesia", and he entered the Vienna "Alemannia"-fraternity on 29 January 1872. Known by his Kneipname (fraternity name) "Stiefel" ("boot"), he soon won a reputation as a great fighter with the sabre. One is tempted to assume that he devoted more time to his fraternity than to his studies. In September 1872 , Zboril became the "Alemannia's" Senior (similar 
to the president of a club). German student-fraternities are now often regarded as a bunch of hard-drinking, duelling lads, pre-Nazi in their political views: But whereas duels were an important part of the fraternity life (being thought a means to train a student's character), and harddrinking far from unknown, it would be wrong to reduce the fraternities to these stereotyped images. The fraternities of the 1870 s were certainly German-nationalistic and liberal, but neither antiSemites (there were also several Jews in the "Alemannia") nor "small-German" in the Bismarckian sense of the word. They favoured instead a "greater-Austrian" political order for Central Europe. To ensure its conservative character, the "Alemannia" was reconstituted as a Corps in December 1872, putting special emphasis on the duel as a measure of strengthening a student's personality and thus distancing itself from the "reformist" fraternities opposing the duel. Between 1872 and 1876, Zbořil himself fought ten duels ("Mensuren"), ${ }^{2}$

\section{With the Austrian Artillery}

1873 was an important year for Adolph Zbořil. In March, he registered for military service. This was compulsory and consisted of three years active service, with a further nine years in the reserve. High school graduates could volunteer to serve only one instead of three years and, after passing several exams, become reserveofficer-candidates. Zbořil thus registered for service as a "one-year-volunteer" with the Infantry Regiment No. 49.

In May 1873, however, his father apparently lost his fortune in the stock-market collapse which reduced thousands of families to misery. Although he managed to retain his trading agency, Jakob Zboril lost both his position with the Vienna saving bank's council as well as his agency's representations for several large companies. For Adolph Zboril, this meant the loss of the considerable cheques from home.

In the autumn of 1873 , Adolph Zboril started his military service not with the infantry, but with the artillery. He joined the Fortress Artillery Battalion No. 3 where he served for three years, first in Vienna and then in Komarom (Hungary). He probably became a corporal/cadet-officer, but failed to receive an officer's commission; unfortunately, the documents in the War Archives in Vienna contain no further details of his military service.
Throughout this time, Zboril was a non-active member of the "Alemannia". In late 1876, he continued his studies for a short time, but left for Switzerland soon afterwards, working for the "Institution Techniques et Commerciale" at Stafa near Zurich. Later, he returned to Vienna to work at the State Railways' Machinenfabrik.

\section{Out for Africa}

Possibly due to the family's financial situation, the two elder Zbořil brothers, Adolph and Josef (born 1852) left Europe for South Africa in 1878 or 1879. Josef is said to have fought with the British in the Zulu War of 1879 and later with the garrison of Middelburg in 1881, before settling in Johannesburg, Adolph, however, started in the Cape Colony as a merchant. ${ }^{4)}$

The information that he fought with the Boers at Majuba has not been verified - it is more likely that he immigrated to the Transvaal only in 1883 or 1884. According to a romantic version, he had to leave Cape Colony together with his fiancée. Miss Edith Priddey (born 1864), because her parents had forbidden their marriage.

Before we continue with Adolph Zboril's biography, we should perhaps mention that his younger brother, Eduard Wenzel Zbořil (born 1857), a second lieutenant in the Austrian army reserve, followed his brothers. He came to East Africa in early 1886 in the service of the German East Africa Company, but already died there in December that year. ${ }^{5}$

\section{Joining the Transvaal Artillery}

On 8 February 1886, Adolph Zbořil applied for the vacant position of captain of the Transvaal artillery. On 1 July 1886, he was provisionally appointed as "administrateur en Adjutant van het Rijdende Artillerie en Politiekorps der ZuidAfrikaanschen Republiek". This appointment was made definitive in December, Zbořil's salary being $£ 275,00$ a year. ${ }^{6)}$

Nonetheless, Zboril kept his small business which he had probably started soon after immigrating to the Transvaal, his most important goods being gunpowder and brandy.7) 
Scientia Militaria, South African Journal of Military Studies, Vol 18, Nr 2, 1988. http://scientiamilitaria.journals.ac.za

23

$\operatorname{lec} \frac{131}{86}$

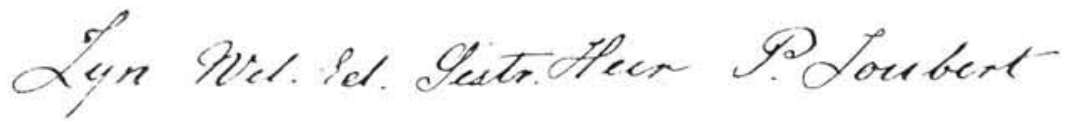
Generdal der Z. Q. T?

Mel. id. Oeste Slear.

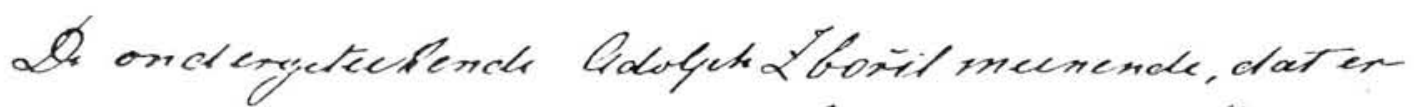

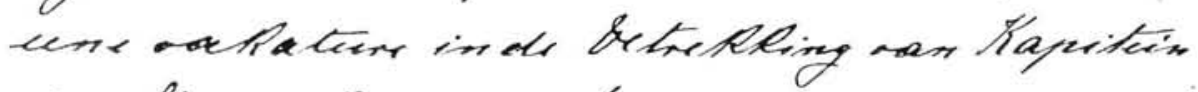

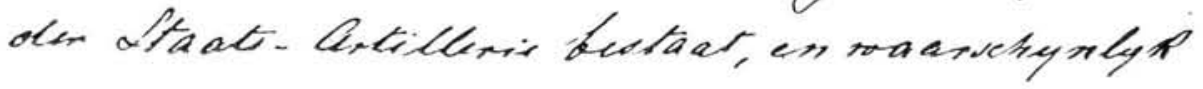

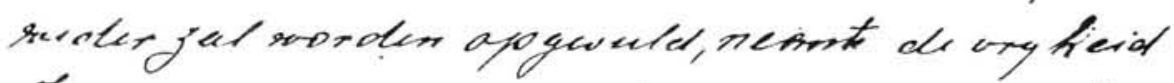

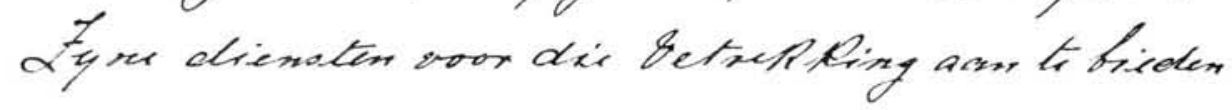

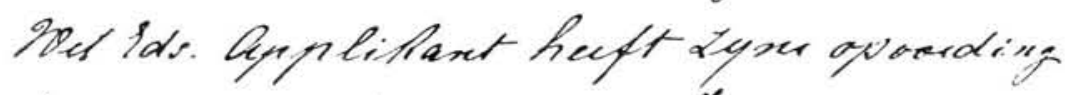
genoter in une dehod voor dingemieuren en heeft max dast a claren med wittellening

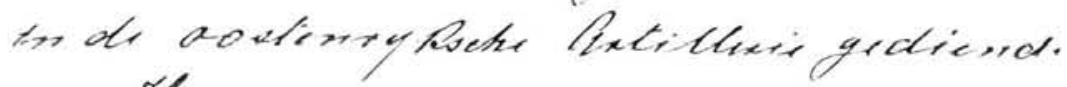

Hly vou genuillig byn cen maand af maen alo proctiyd to dienesen, en ton her groal

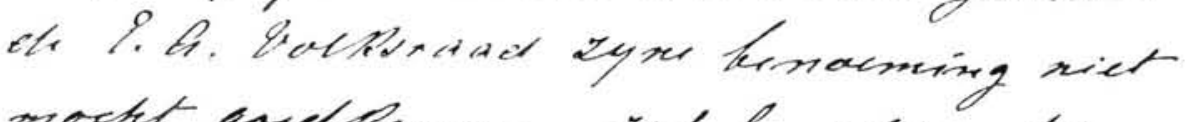
moctet gordereusen, gat hy alken tor

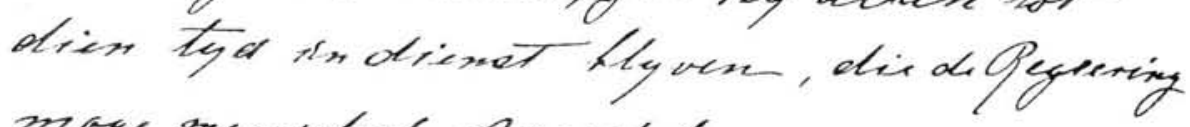
mage paenseticly tp oordelen.

len gunstig asetwoord afruadi kerous, brefp bly de eer atich th racmen

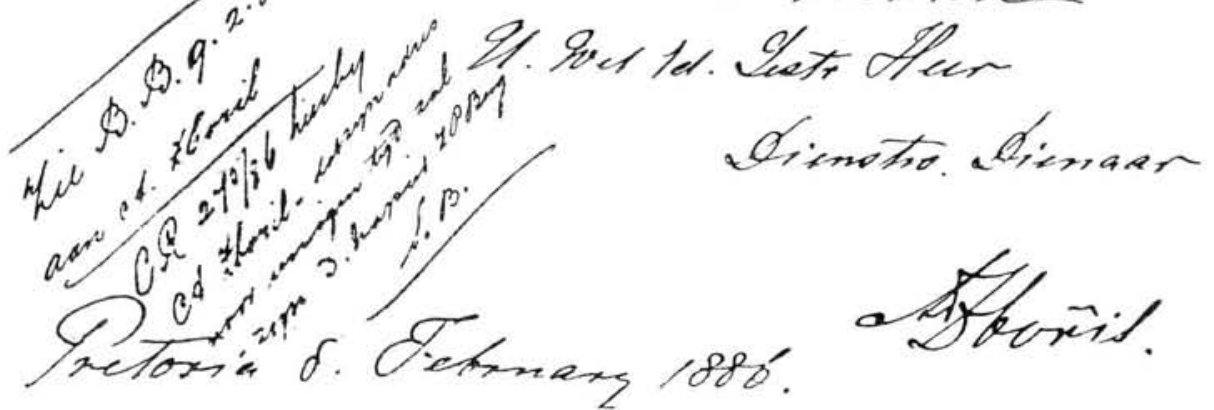

Zboril's application for the vacant post of captain and administrateur of the Transvaal artillery, Pretoria, 8 February 1886 (Source: Transvaal Archives Depot, SS 1237: R 3017/86, p. 23)

48 


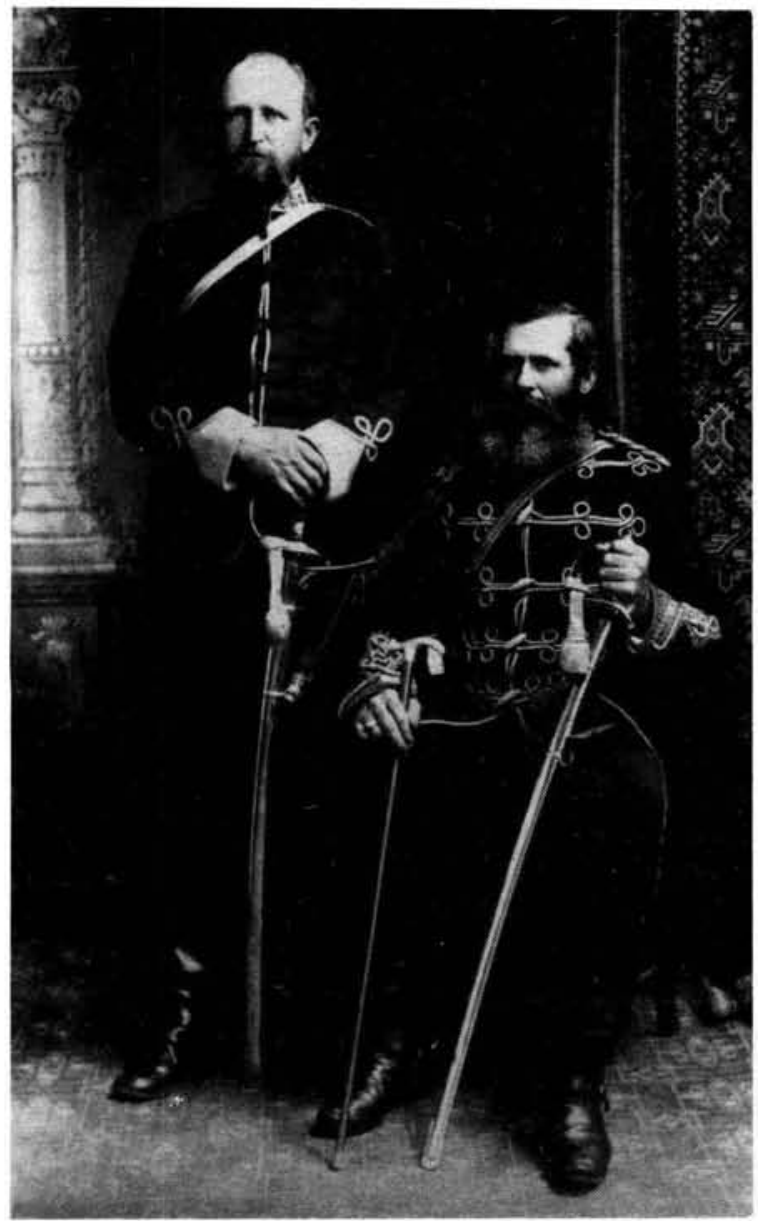

In 1886, the Transvaal artillery had about a dozen guns (which qualified for any army museum, as Adolf Schiel, who joined the artillery in 1888 , noted later) and numbered six officers and 120 other ranks. ${ }^{8)}$ Commanding officer was Commandant Henning Pretorius - Captain Zbořil was the second-ranking officer and apparently the only one with European military training. Zboril obviously tried to improve the organization and efficiency of the Transvaal artillery: already on the day after his appointment he demanded additions to the artillery barracks in Pretoria. ${ }^{9}{ }^{9} \mathrm{He}$ had the oxen (which were still used to draw at least some of the guns) replaced with horses and when Adolf Schiel, a former Prussian Hussar, became Lieutenant in 1888-89, Zbořil's reformist ideas had better chances of realization than before. According to Schiel's memoirs, Zbořil had not managed to convince his superiors, notably Commandant-General Piet Joubert, of the importance of a modern and efficient

Capt A. Zboril (standing, left), together with Commandant Henning Pretorius, the commander of the Transvaal Rydende Artillerie en Politiekorps, ca. 1890. (Photo: Africana Museum, Johannesburg)

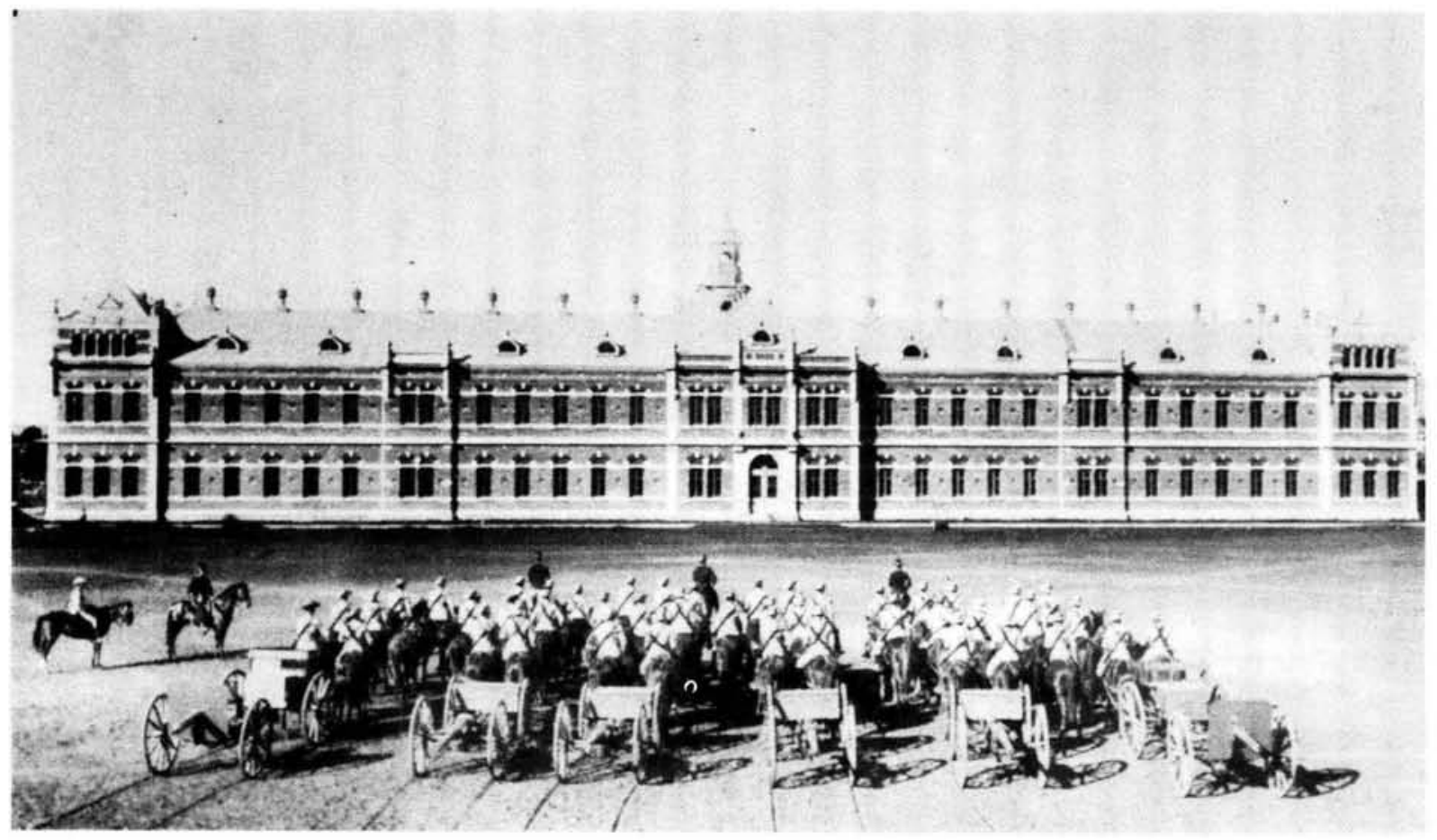

Transvaal artillery in front of the artillery barracks in Potgieter Street (Photo: Cultural History Museum) 
artillery force - and, despairing, devoted more time to his "remarkably beautiful wife" than to the artillery. ${ }^{10)}$ Still - and despite their later rivalries Schiel wrote rather fondly of Zbořil.

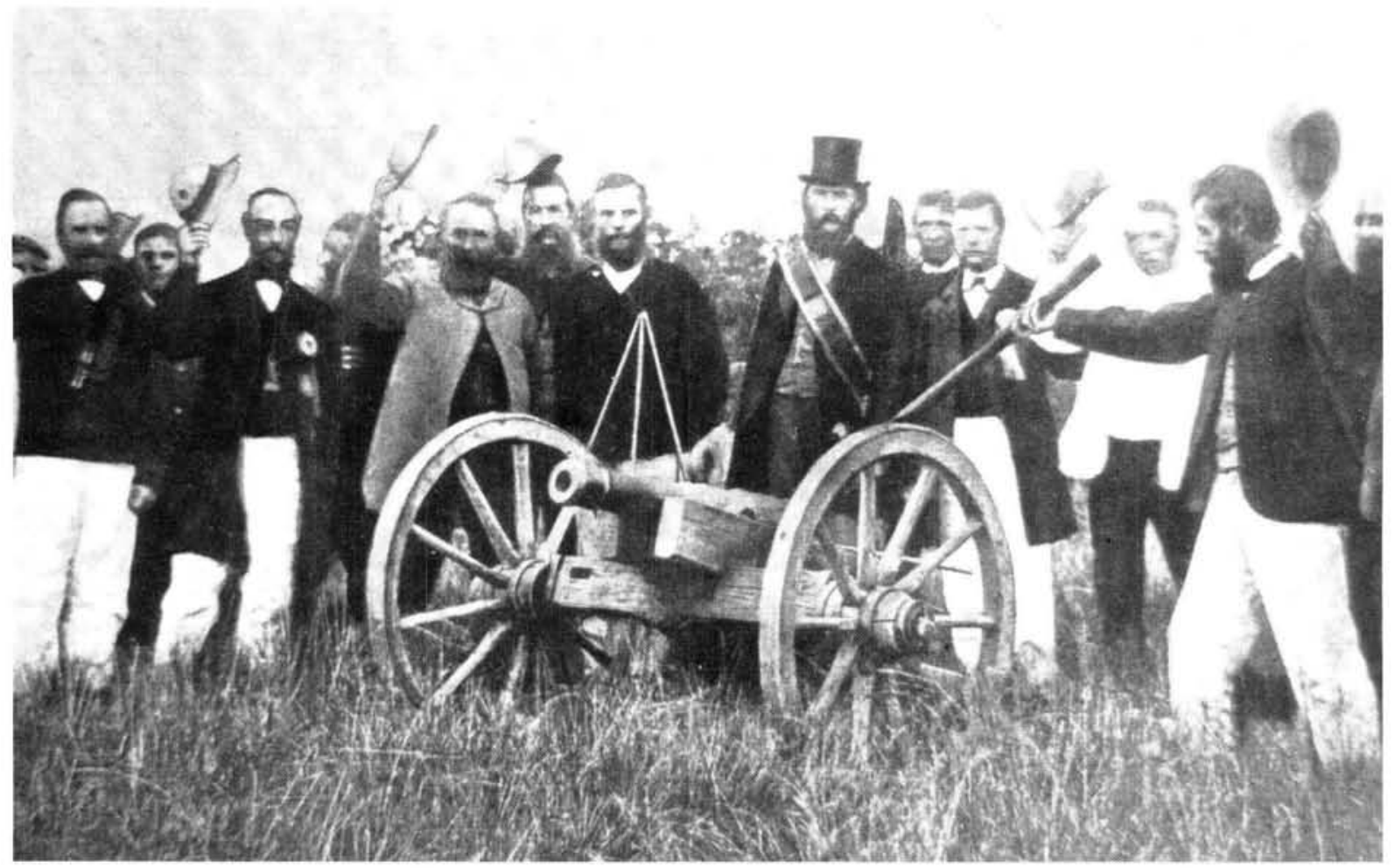

Heavy artillery were rare in the early years of the South African Republic. President T.F. Burgers (with top hat) was nevertheless interested in the founding of an artillery unit and even bought guns abroad in 1874. Here a shot is fired with a muzzle loading gun. This was one of the first pieces which was acquired by the Transvaal Artillery

(Photo: Cultural History Museum)

Among Zboril's more interesting contributions to the South African military history ranks the "yzeren fortje" or "yzeren forten" (iron forts) which he designed in 1887. These forts were made of heavy armour plates which were transportable and could be put together comparatively easily. The walls and roof of armour plates must have made conditions inside quite hot for the 20 or 25 soldiers who found place (and refuge) in the fort. Altogether at least three forts were made and the first of these were dispatched to Klipdam and Pietersburg in April 1888. One of the forts, "Fort Hendrina", is today preserved as a national monument in Louis Trichardt. ${ }^{11)}$

\section{Austrian uniforms for the Transvaal Artillery}

In the 19th century, military efficiency was often regarded as synonymous with smart appearance. (In fact, these views are still aired today, despite the fact that, for example, the Israeli Defence Forces have demonstrated most clearly that smart uniforms are not necessarily a prerequisite for military success). Whatever the re- lationship between combat-effectivity and smart outlook might be, the Transvaal artillery of the mid-1880s sadly lacked both. Less than completely successful in enhancing the unit's military efficiency, Zboril at least managed to acquire new uniforms for his men. As he was Austrian by birth (and, until 1891, also by citizenship), it was probably only logical that he had these uniforms made of typical Austrian cut, some items even being manufactured in Vienna.

The uniform came in two versions, of dark blue cloth for winter and parade wear and of light sand-grey drill for summer and field dress. Of rather loose-fitting cut, the jackets had two shirt pockets and a low standing collar. The facing colour was sky blue - which was remarkable at least: Most artillery forces tended to adopt "symbolic" facing colours such as red (Britain, Austria, and many others), black and red (Prussia), or yellow and black (Italy). But sky blue? It is not clear who opted for the sky blue facings, but, considering Zborill's background, two explanations are possible. Dark blue uniforms with sky blue facings were worn by one of the proudest 


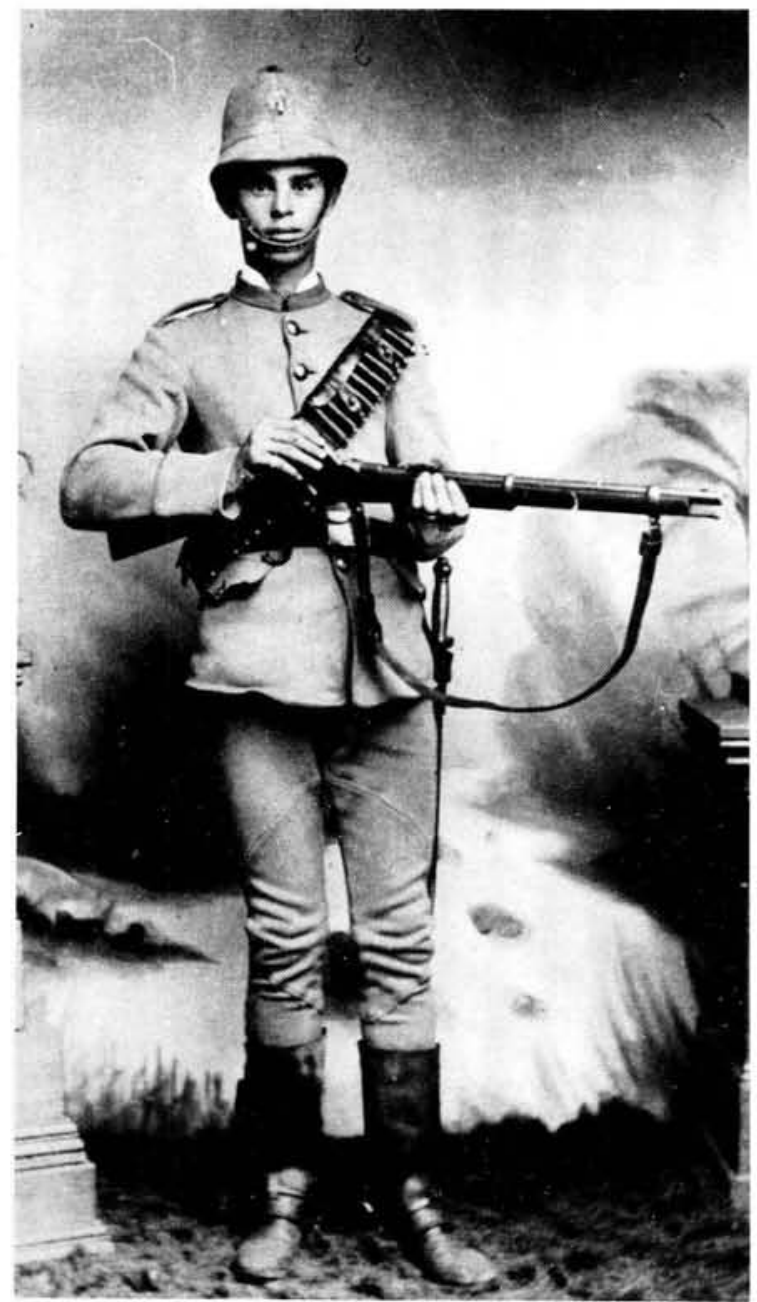

Transvaal artillery, field service dress, ca. 1890 (Photo: SADF Documentation Service, Neg. No. 700/7/02)

regiments of the Austro-Hungarian Army, the famous Infantry Regiment No. 4, "Hoch-und Deutschmeister". This regiment was recruited in Vienna ("Wiener Hausregiment") - but as Zbořil himself had no affiliations with this regiment, this possibility is less than completely convincing. More likely is another explanation: Zbořil's student fraternity was known as the "blue Alemannia", sky blue being the distinguishing colour of technical faculties. The "Alemannia" had sky blue caps and fraternity students wore a narrow band beneath their jackets; this band was striped black-blue-gold. Although we have no proof of this thesis, it appears possible that Zbořil chose sky blue facings as a reminder of his student days. And as artillery was always considered a "technical" arm, this choice would have been a quite logical one, too.

These blue or sand-grey jackets were matched by blue visored caps of typical Austrian design and blue or sand-grey breeches, worn with

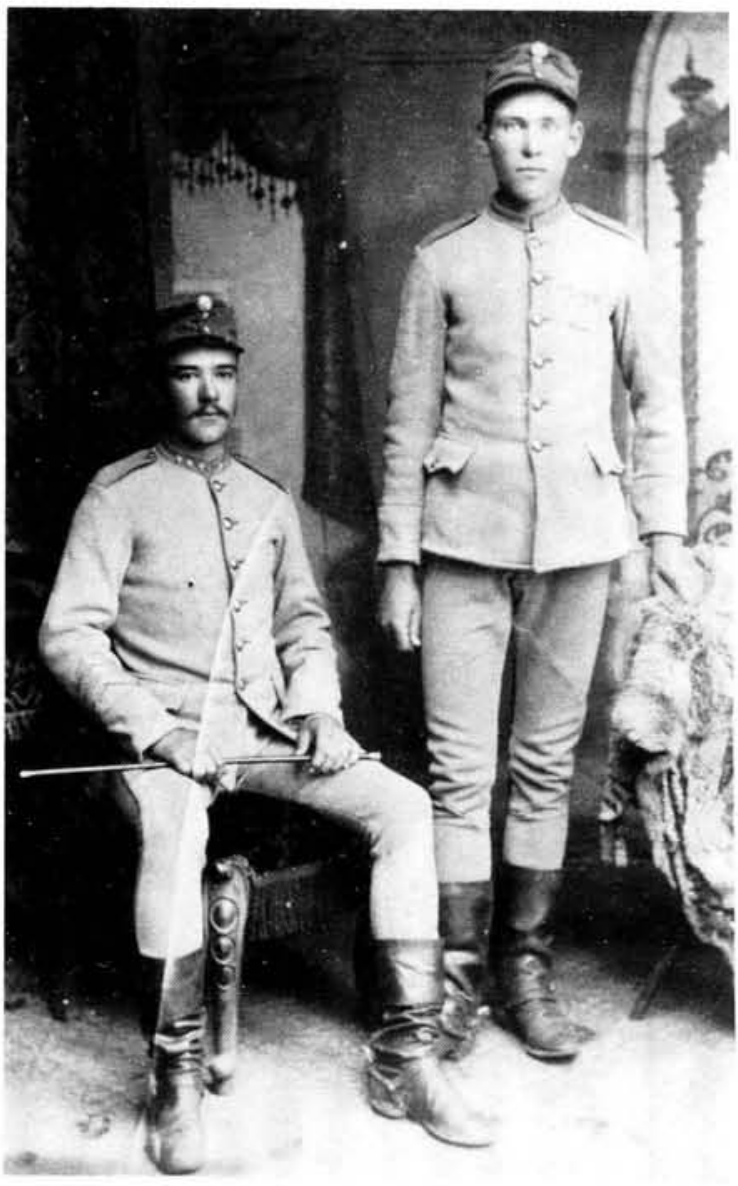

Sergeant and Gunner of the Transvaal artillery. The soldiers' names are given as J. Myburg and D. Krige. As Jacobus Petrus Daniel Kriger (!) served with the artillery from May 1891 through July 1895, and Johannes Matheus Myburg from November 1893 through June 1894 , we can assume that Kriger (or Krige) is the sergeant and that this picture was taken in early 1894. Note the sergeant's insignia of rank: three stars on each collar and three chevrons on the right forearm. (Photo: Transvaal Archives Depot, Neg. Nr. 8423)

black boots. A white sun helmet, sabre (for the mounted gunners and non-commissioned officers) or short straight sword (for the nonmounted gunners), and carbine or revolver completed the outfit. As rank-badges, non-commissioned officers had at first one, two or three sixpointed stars (cut from white cloth) on each collar, supplemented by an equal number of gold chevrons on the right forearm. Later, the stars were abolished and the chevrons worn on both arms.

Officers wore the black Austrian officers' caps and dark blue Hussar-style patrol jackets with black braiding across the chest and sky blue facings, their rank being indicated by gold sixpointed stars on the collar in typical Austrian fashion. Again, their stiff caps were modelled on the Austrian example, only the Emperor's initials ("FJI" for Franz Joseph I.) were replaced by the 
Dark blue tunic (below, left) with light blue piping and facings, as worn by the Transvaal artillery in the early 1890 s. Some photographs show grenade insignia on the shoulder straps and a cap in dark blue with light blue turnups. The NCO's insignia of rank (the chevrons on both arms) were only introduced around 1894, before that date the chevrons were worn on the right arm only
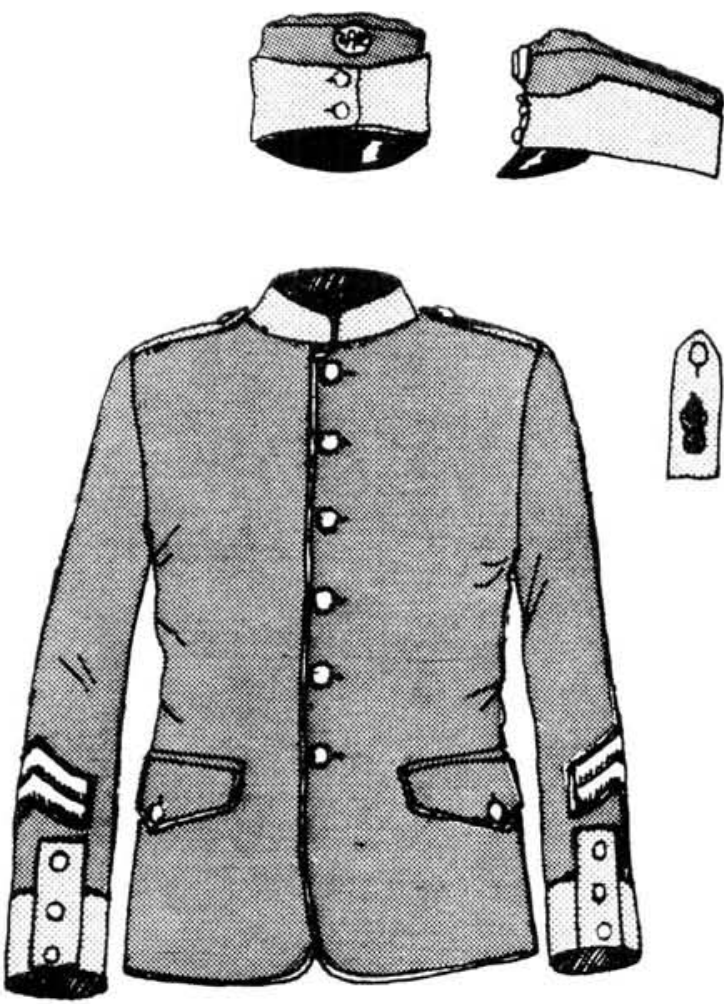
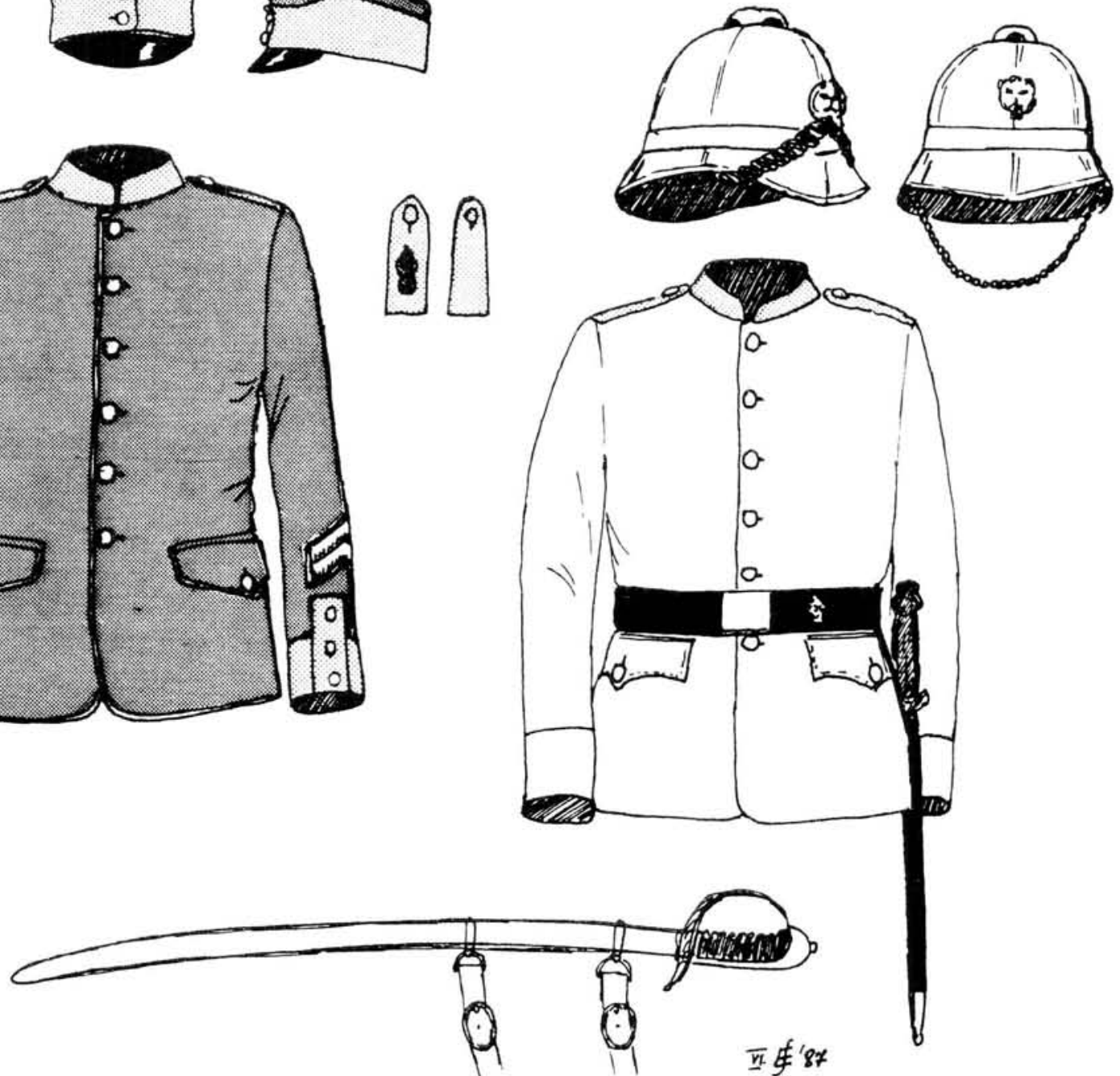

Field-dress of khaki/light grey colour with sky blue facings (top, right). The sunheimet was apparently of off-white/khaki colour and had a characteristic lion's head-badge in front, used to hook up the chin-strap. Note the black belt and short sword apparently worn by gunners not mounted. The sabre worn by mounted gunners is shown below
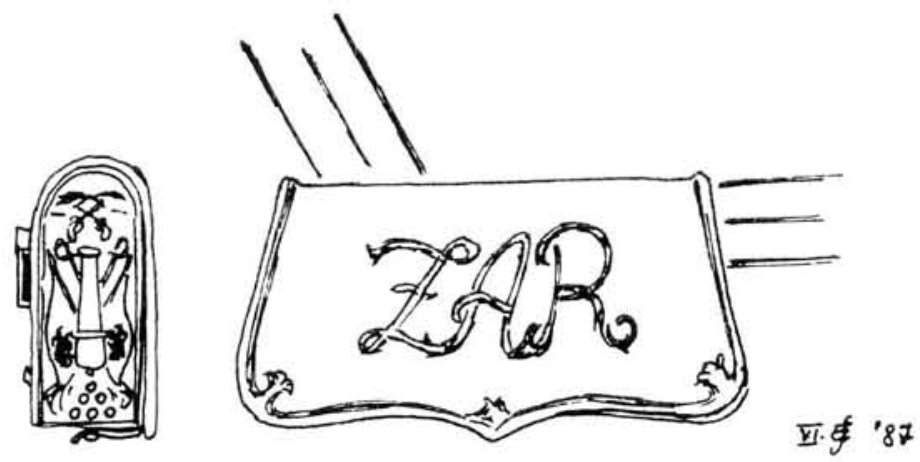

Officer's pouch, showing the ZAR letters (from an original in the National Museum of Military History, Saxonwold) 
familiar letters "Z.A.R." on the cap's rosette. Officers carried sabres, of course. In addition, a silver-plated pouch, bearing the letters "Z.A.R.", was worn on a silver pouch-belt over the left shoulder - which followed the Austrian pattern so closely that for the pouch's sides the Austrian design was used without modifications, down to the double-headed eagle motive on the flags. ${ }^{12)}$

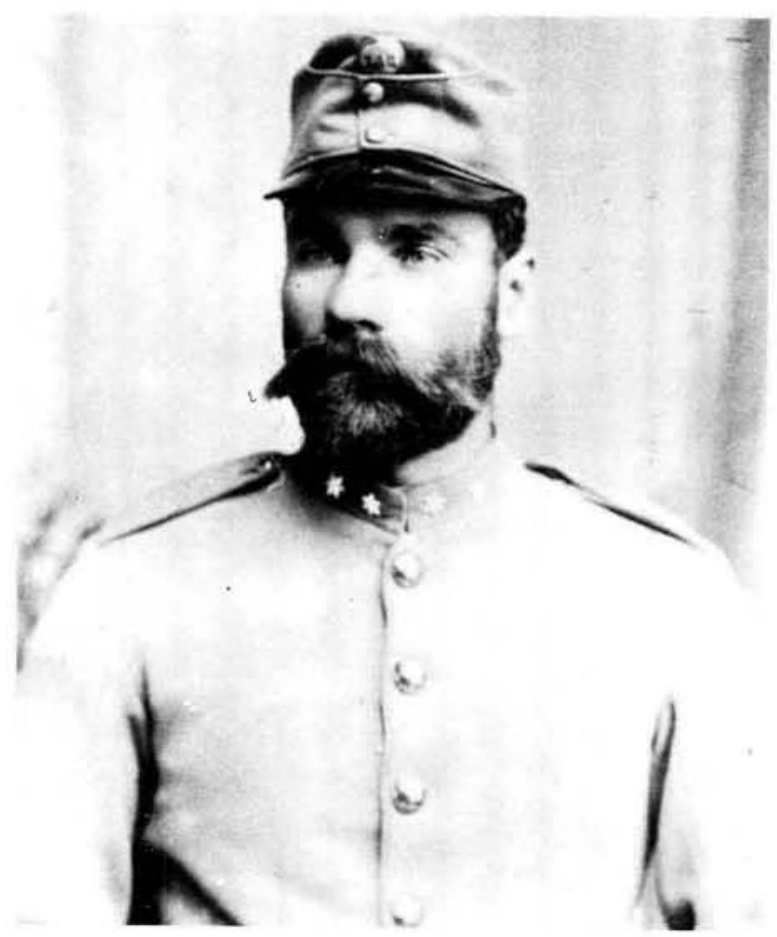

Corporal of the Transvaal artillery. This photograph shows to good advantage the Austrian field cap (with the rosette bearing the letters "ZAR") in sky blue colour with black visor and the field blouse with the two stars on the collar. (Photograph: SADF Documentation Service, Neg. Nr. 7000/7/65)

Altogether, these uniforms were smart but practical and less cumbersome to wear than some contemporary designs - we have only to think of the "Prussian" full dress uniforms worn by the Oranje Vrystaat artillerymen! They were worn for about eight years until replaced by the betterknown braided blue hussar-style tunics in the late 1890s. The sand-coloured field blouses were worn even longer, well into the Second Anglo-Boer War. The Austrian officers' rank badges were copied by the Z.A.R.-Police as well as by most volunteer corps raised in the Transvaal in the 1890s. Even burgher officers in the commandos sometimes wore these badges of rank.

\section{The Final Years}

When Lieutenant Schiel left the artillery in June 1889 to become native-commissioner of the

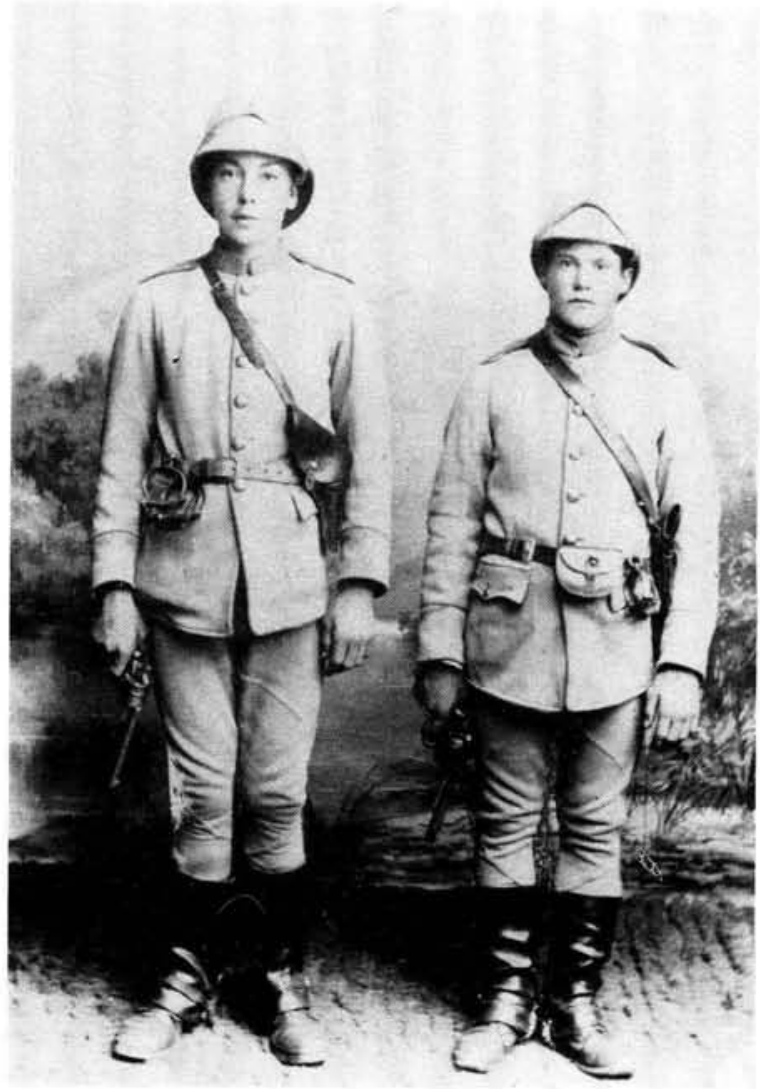

As the police was part of the artillery, policemen wore the same uniforms. Note the difference in equipment between these two policemen whose names are given as S. du Plessis and J. Badenhorst. (Photograph: Transvaal Archives Depot, Neg. Nr. 8477)

Spelonken district in the northern Transvaal, he was promoted captain - which Zboril who held the same rank, considered an affront. Two years later the rivalries between Zboril and Schiel became public when the Administrateur accused his former lieutenant of abusing the powers of his office. During an inspection tour to Fort Hendrina in October 1891, Zboril was told that a black maid of Schiel had been hit so hard by her employer that she died soon afterwards. Zboril initiated an official investigation in the course of which more allegations were brought up against Schiel. According to the German, however, the girl had tried to commit "indecent acts" with his five-year-old son, having pulled down his trousers. When Schiel had noticed this, he had whipped the girl and then sent her off to a local induna. Three months later, in July 1891, the girl had mysteriously died - and, as Schiel put it, the rumours linking him to the girl's death were unfounded and set up by merchants hostile to him. ${ }^{13)}$

Schiel was finally acquitted of the charges. Zboril was said to have abused his official position to harm Schiel, although from the documents it 
would seem that Zboril's allegations were not completely unfounded. The rumours about Schiel's behaviour never died and were again brought forward in 1898, when signatures were collected to protest Schiel's appointment as head of the Transvaal prison service. ${ }^{14)}$

In the same year the Schiel affair took place, Zboril finally became full citizen of the South African Republic on 6 November 1891. ${ }^{15)} \mathrm{His}$ relations with his superiors deteriorated, however. This was in part due to his being often drunk and altogether showing a behaviour "die onhoudbaar is voor 'n Afrikaner", as a commission appointed to inquire into the state of the artillery concluded. ${ }^{16)}$ Zboril consequently was relieved of his duties. From late 1893, Lieutenant J.W. Bosman served as acting Administrateur of the artillery. In February 1894, Zbořil finally resigned his commission. ${ }^{17)}$

\section{On to Rhodesia}

Already a civilian, Zbořil took part in the Malaboch campaign of 1894, joining the commandos as a sutler. ${ }^{18)}$ At the same time, he had the dubious pleasure to see his rival Schiel appointed as his successor. ${ }^{19}$ )

Probably in 1895, Adolph Zboril left the Transvaal and went north to the territories of the British South Africa Company. When the uprising started in Matabeleland in 1896, he volunteered to serve as a trooper with the Umtali Contingent. On 27 June 1896, he died of sunstroke at Salisbury (now Harare, Zimbabwe). ${ }^{20 ;}$ His widow, then 33 years old, married Johannes A.F. Fich on 11 August 1897 in Johannesburg, leaving for Cape Town soon afterwards. ${ }^{21)}$

\section{Conclusions}

It is difficult to present a fair assessment of Zboril's achievements as administrator of the Transvaal artillery. He failed to transform the odd collection of old guns he found in 1886 into a modern artillery force - but given the conditions prevailing in the Transvaal at the time, this was probably a task demanding super-human energies: it was not until the Jameson Raid of 1895/ 96 that the need for a modern and efficient artillery force of European standard was recognized by most Boers. Zboril laid the foundations on which his successors were able to reform the Staatsartillerie into the élite force which became justly famous during the Anglo-Boer War of 1899-1902.

- Dr Erwin A. Schmidl is a historian at the Austrian Army Museum in Vienna.
Notes:

1. I am very much indebted to the late Hofrat Dr. Walter Rabe, the noted Austrian student historian, who supplied most of the data for Zboril's European career. See also Zbofil's letter to Cdt.-Gen. Joubert, 1886 February 8 (Transvaal Archives Depot - thereafter: TAB - SS 1237: R 301786, CR 131/86)

2. This information comes from Dr Rabe's files, who also authored a short biography of Zboril recently, emphasizing his role in the "Alemannia": "Adolf Zboril - Wiener Alemannen-senior und Capitän der Burenartillerie". In: Corps Alemannia Wien zu Linz - Corpsnachrichten, № 245 (1986), 13-22, and 253 (1 87), 13-18

3. Zboril's Grundbuchsblatt: Österreichisches Staatsarchiv/Kriegsarchiv, Vienna: GB Wien (vor 1865). For his help in tracing this document and an entry in the War Ministry's registers about his transfer from the infantry to the artillery, I am grateful to Dr Rainer Egger of the War Archives.

4. This intormation comes from a newspaper clipping, dated 29 August 1887 (unfortunately the newspaper's name is not given), which Dr Rabe found in the "Alemannia's" files: "Der "Fuchsmajor' im Transvaal". "Fuchsmajor" reters to Adolph Zboril's activities as instructor to junior fraternity members. According to the "Alemannia's" address lists of 1881 and 1883, Zbofil lived in Molteno (District Albert), Cape Colony.

5. ibid. and Eduard Zboril's personal files (Kriegsarchiv, Vienna: GB Abg. IV-5/174 and Qualifikationslisten, Fasz. 3348)

6. TAB: SS 1237: R3017/86, pp. 19-21. Over the years, Zboril's salary rose to $£ 450,00$

7. As in. 4 .

8. Adolf Schiel, 23 Jahre Sturm und Sonnenschein in Sudafrika (Leipzig: F.A. Brockhaus, 1901), 176; O.J. O. Ferreira (ed), Geschiedenis Werken en Streven van S.P.E. Trichard (Pretoria: Human Sciences Research Council, 1975), 80

On the Staatsartillerie: D.J. Haupt, "Die Staatsartillerie van die SuidAfrikaanse Republiek", MA thesis, Pretoria 1946.

See also: "Die Staatsartillerie van die ZAR", Militaria 6/2 (1976), 1-15, and Jan Ploeger, "Uit die geskiedenis van die 'Corps Staatsartillerie' van die Zuid-Afrikaansche Republiek", Militaria 15/4 (1985), 1-10.

9. TAB: SS 1243: R 3256/86.

10. Schiel, 23 Jahre, 175.

11. Letter Cdt-Gen to Cdr/RA\&P. Pretoria, 1888 April 10 (TAB. SS 1666 : R5853/88). For additional comments I am indebted to Colonel (ret.) Dr Jan Ploeger, who contributed immensely to my research, as well as to Mr Schoeman of the National Monuments Council, Pretoria, who kindly supplied me with further data on Fort Hendrina. Remaining parts of the "old" iron forts were removed from the Staatsartillerie Camp in 1897 (TAB. KG 250: CR 4657/1897).

12. This description has been put together from various photographs and original uniform items - and I wish to thank the stafts of the Africana Museum and the National Museum of Military History (both Johannesburg), the Military Museum Fort Klapperkop (Pretoria) and the Boer Republics' War Museum (Bloemfontein) as well as the SADF's Information Bureau for their heip. For additional information I am indebted to Miss Fiona Barbour, Prof Dr J.H.G. de Villiers and Mr A.B. Walmsley. See also Trichard's memoirs (as in. 8), p. 81.

13. TAB: SS 2989 and 2990 . The documents relating to this investigation fill no less than two volumes! See also Melt van Niekerk, "Adolf Schiel en die Duitse Kommando", Argiefjaarboek vir Suid-Afrikaanse Geskiedenis 14/2 (1951), 35-208, here $61-64$.

14. See $T A B$. SS 2990: CR 1085, pp. $77 \mathrm{ff}$. Although it is very difficult to assess these documents after nearly 100 years, I cannot share Van Niekerk's harsh condemnation of "Zboril se laakbare poging om Schiel te benadeel" (p. 64)

15. TAB. SS 3011: R $11529 / 91$

16. D.J. Haupt, "Die Staatsartillerie van die Suid-Afrikaanse Republiek". In: Historiese Studies, Vol. 8 (April, 1948), 175-191, here 186.

17. TAB. SS 4017: R 14255/93.

18. TAB: KG 78: CR 1630/94 and KG 111: CR 1236/95. On this campaign Zboril lost his saddle and gun and demanded reimbursement from the Commandant-General.

19. Jaarrapport van den Commandant-Generaal over 1894 (TAB. ZAR-Publ. Vol. 111).

20. A death certificate is in $T A B$. SS 6661: $R$ 11517/97. For additional information, I am indebted to the staff of the National Archives of Zimbabwe who were most helpful in establishing the events surrounding Zboril's death.

21. TAB: SS 6433: R 7119/97 and SS 6661: R 11517/97. 